\title{
UJI EFEKTIVITAS ANTIDEPRESAN EKSTRAK BATANG SERAI (Cymbopogon nardus (L.) Rendle) TERHADAP MENCIT PUTIH JANTAN (Mus musculus)
}

\author{
Delisma Simorangkir, Parhan, Atika Patni Suri \\ InstitutKesehatan Deli Husada Deli Tua \\ e-mail:simorangkirdelisma@gmail.com
}

\begin{abstract}
Depression is a mood disorder that is characterized by profound and sustained sadness and sadness until the loss of life passion. The side effect of using synthetic antidpessant drugs is dependence on antidepressant drugs circulating in the community, including the psychotropic drug class. Therefore we need antidepressant drug that are safe to use. Lemongrass which contains eugenol is thought to have the potential as an antidepressant that works by inhibiting the Mono Amine Oxidase enzyme. This study aims to determine the effectiveness of antidepressant citronella extract (Cymbopogon nardus (L.) Rendle) on male white mice. This study used 5 treatment groups namely CMC Na $0.5 \%$, amitriptilyn, lemongrass extract dose $1.5 \mathrm{mg} / \mathrm{kgBB}, 15 \mathrm{mg} / \mathrm{kgBB}$ and $150 \mathrm{mg} / \mathrm{kgBB}$. Antidepressant testing was determined based on immobility time using the forsed swim test method. Data analysis using statistics was tested for normality and continued with the One Way Anova method with a 95\% confidence level. The results showed that the most effective treatment group as an antidepressant was amitriptilyn followed by lemongrass extract dose $150 \mathrm{mg} / \mathrm{kgBB}$ comprated to dose $1.5 \mathrm{mg} / \mathrm{kgBB}$ and $15 \mathrm{mg} / \mathrm{kgBB}$. The conclusion of this study is that lemongrass extract dose $150 \mathrm{mg} / \mathrm{kgBB}$ has the effectiveness as an antidepressant but is no more effective than the comparison of amitriptilyn.
\end{abstract}

Keywords: Depression, Immobility Time, antidepressant

\section{PENDAHULUAN}

Depresi adalah gangguan alam perasaan (mood) gejala yang dapat dilihat adalah dengan kemurungan dan kesedihan yang mendalam dan berkelanjutan hingga hilangnya gairah hidup, tetapi tidak mengalami gangguan dalam menilai realitas (reality Testing Abiliti/RTA, mash baik), kepribadian tetap utuh (tidak mengalami keretakan kepribadian/splitting of personality) perilaku dapat terganggu tetapi dalam batas-batas normal (Hawari,2018). Depresi merupakan gangguan neurobiologi pada otak dengan gejala atau fenomena yang kompleks serta etiologi yang hingga sekarang masih belum jelas (Lisnawati, 2015).

Depresi dapat ditangani atau diobati menggunakan obat antidepresan. Antidepresan adalah adalah obat-obat dengan efek 
positif memperbaiki mood umumnya dapat menimbulkan efek samping yang serius. Efek samping dari penggunaan obat sintetik antidepresan yaitu ketergantungan karena obat antidepresan yang beredar di masyarakat termasuk golongan obat psikotropika. Maka dari itu diperlukan obat antidepresan yang aman digunakan. Alternatif obat antidepresan dapat diperoleh dari bahan alam yang mudah ditemukan (Lisnawati, 2017).

Sebagai alternatif, kemudian dikembangkan suatu terapi dengan menggunakan tanaman obat yang berpotensi sebagai antidepresan yaitu tanaman serai (Cymbopogon nardus (L.) Rendle).

Kandungan senyawa kimia pada serai adalah eugenol, eugenol merupakan golongan dari flavonoid. Eugenol dapat menghambat enzim Mono Amine Oksidase dan reuptake neurotranmiter monoamin (Istriningsih, 2018).

\section{METODE PENELITIAN}

Penelitian ini dilakukan di Laboratorium Kimia Fakultas Farmasi Institut Kesehatan Deli Husada Deli Tua dan uji antidepresan dilakukan di Laboratorium Farmakologi Fakultas Farmasi Institut Kesehatan Deli Husada Deli Tua. Penelitian dilakukan selama \pm 2 bulan, dimulai dari bulan Februari 2019.

Pembuatan ekstrak Batang serai Ekstraksi batang serai (Cymbopogon nardus (L.) Rendle) dilakukan dengan metode maserasi. Ekstrak batang serbuk simplisia ditimbang dimasukkan kedalam sebuah wadah, dituangi 75 bagian etanol 96\%, ditutup, kemudian dibiarkan selama 5 hari sambil sesekali diaduk serta terlindung dari cahaya, selanjutnya diserkai, dan diperas. Dicuci ampas dengan etanol $96 \%$ secukupnya hingga diperoleh 100 bagian. Selanjutnya dipindahkan ke dalam bejana bertutup, dibiarkan ditempat sejuk terlindung dari cahaya selama 2 hari. Dienap tuangkan atau disaring (Ditjen POM, 1979). Hasil maserat yang diperoleh dipekatkan dengan menggunakan rotary evaporator pada temperatur $\pm 40^{\circ} \mathrm{C}$ sampai diperoleh ekstrak kental.

\section{Perlakuan Hewan Uji}

Pengujian antidepresan menggunakan metode forced swimming test dan dilihat Imobility Time pada hewan uji mencit, dengan cara mencit dimasukkan kedalam aquarium ( $44 \times 20,5 \times 23$ $\mathrm{cm})$ berisi air $\left(25^{\circ} \mathrm{C}\right)$ dengan ketinggian $15 \mathrm{~cm}$. Hewan uji yang depresi aktivitas motoriknya menurun sehingga cenderung diam di suatu tempat dan tidak bergerak. Setelah 1 jam setelah pemberian sediaan uji secara oral, mencit direnangkan. Durasi Imobility dilihat pada menit ke 2 dalam waktu 6 menit. Imobility time adalah jumlah satuan waktu tidak bergerak seluruh bagian tubuh mencit yang diukur selama mencit berenang pada metode Forced Swimming Test (Praja, 2016 dan Nuzband K N, 2014). 


\section{Pemberian Ekstrak batang Serai}

Masing masing ekstrak disuspensi dengan CMC-Na 0,5\%, larutan ekstrak batang serai dengan dosis $1,5 \mathrm{mg} / \mathrm{KgBB}$, ekstrak batang serai dosis $15 \mathrm{mg} / \mathrm{KgBB}$ dan ekstrak batang serai dosis $150 \mathrm{mg} / \mathrm{KgBB}$ diberi secara peroral sebanyak 0,3 $\mathrm{mL}$.

\section{Pemberian Amitriptilyn}

Dosis terapi amitriptilin pada manusia adalah $25 \mathrm{mg}$. Konversi dosis amitriptilyn untuk mencit, yaitu: $25 \mathrm{mg} \times 0,0026=0,065$ $\mathrm{mg} / 20$ grBB, atau sama dengan dosis amitriptilin adalah 3,25 $\mathrm{mg} / \mathrm{kgBB}$. Amitriptilin dilarutkan dalam CMC Na 0,05\% diberi secara peroral sebanyak $0,3 \mathrm{~mL}$.

\section{HASIL PENELITIAN}

Hasil pengujian antidepresan menggunakan metode forsed swimm test dengan cara menghitung immobility time dengan waktu 6 menit selama 7 hari. Hewan yang digunakan dalam penelitian ini adalah mencit. Mencit dibagi menjadi 5 kelompok perlakuan, setiap perlakuan terdiri dari 3 ekor mencit. Pada perlakuan ini terdiri dari kontrol negatif CMC $\mathrm{Na} \quad 0,5 \%$, kontrol positif (Amitriptilyn), ekstrak batang serai dosis $1,5 \mathrm{mg} / \mathrm{kgBB}$, ekstrak batang serai $15 \mathrm{mg} / \mathrm{kgBB}$ dan ekstrak batang serai dosis $150 \mathrm{mg} / \mathrm{kgBB}$.
Tabel 1. Hasil Uji antidepresan

\begin{tabular}{|c|c|c|c|}
\hline \multirow[t]{2}{*}{ Perlakuan } & \multicolumn{3}{|c|}{$\begin{array}{c}\text { Immobility Time } \\
\text { (Detik) }\end{array}$} \\
\hline & $\begin{array}{l}\text { Hari } \\
\text { ke-1 }\end{array}$ & $\begin{array}{l}\text { Hari } \\
\text { ke-3 }\end{array}$ & $\begin{array}{l}\text { Hari } \\
\text { ke-7 }\end{array}$ \\
\hline $\mathrm{Na} \mathrm{CMC}$ & 174,6 & 128,6 & 223,6 \\
\hline $0,5 \%$ & 7 & 7 & 7 \\
\hline $\begin{array}{c}\text { Amitriptily } \\
n\end{array}$ & 38 & 29,33 & 24,67 \\
\hline $\begin{array}{l}\text { Ekstrak } \\
\text { Batang }\end{array}$ & & & \\
\hline $\begin{array}{c}\text { Serai Dosis } \\
1,5 \\
\text { mg/kgBB }\end{array}$ & 80,67 & 65 & 60,33 \\
\hline $\begin{array}{l}\text { Ekstrak } \\
\text { Batang }\end{array}$ & & & \\
\hline $\begin{array}{c}\text { Serai Dosis } \\
15 \\
\mathrm{mg} / \mathrm{kgBB}\end{array}$ & 68,33 & 56,33 & 48,67 \\
\hline $\begin{array}{l}\text { Ekstrak } \\
\text { Batang }\end{array}$ & & & \\
\hline $\begin{array}{c}\text { Serai Dosis } \\
150 \\
\mathrm{mg} / \mathrm{kgBB}\end{array}$ & 61,67 & 54,33 & 36,33 \\
\hline
\end{tabular}

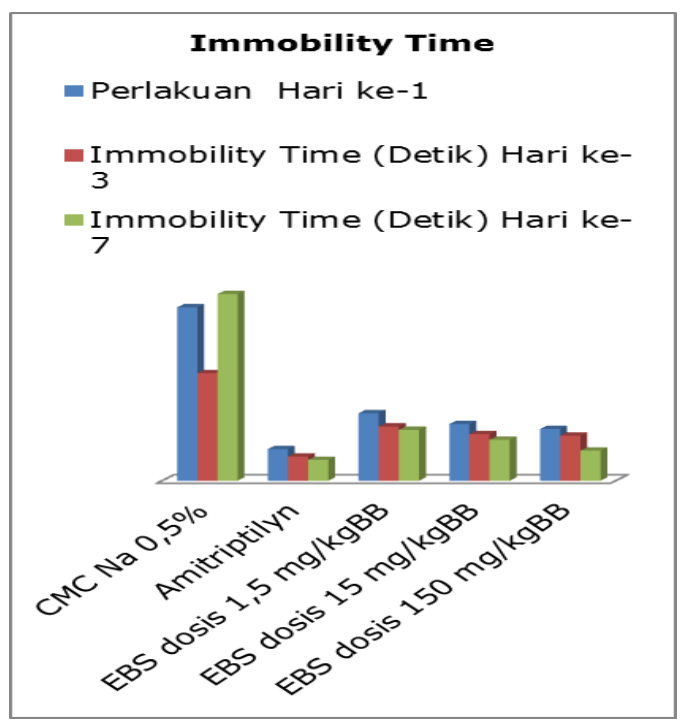




\section{PEMBAHASAN}

Dari hasil uji efektivitas pada tabel 1. dapat diketahui perbedaan waktu diam (Immobility Time) dari masing-masing perlakuan yaitu kontrol negatif (CMC $\mathrm{Na} 0,5 \%$ ), kontrol positif (amitriptilin), dan variasi dosis ekstrak batang serai $1,5 \mathrm{mg} / \mathrm{kgBB}, 15 \mathrm{mg} / \mathrm{kgBB}, 150$ $\mathrm{mg} / \mathrm{kgBB}$.

Hasil

pengamatan

antidepresan yang dilakukan selama 7 hari yang diukur pada hari ke-1, hari ke-3 dan hari-7 menunjukkan bahwa kontrol positif (amitriptilyn $3,25 \quad \mathrm{mg} / \mathrm{kgBB}$ ) memiliki rata-rata immobility time lebih kecil pada hari ke-7 yaitu 24,67 detik jika dibandingkan dengan hari ke-1 yaitu 38 detik dan hari ke-3 yaitu 29,33 detik. Berdasarkan pengukuran immobility time pada hari ke-7 amitriptilyn memiliki waktu diam mencit yang lebih lama jika dibandingkan dengan kontrol negatif (CMC Na $0,5 \%$ memiliki nilai rata-rata immobility pada hari 7 yaitu 223,67 detik, dengan ekstrak dosis 150 $\mathrm{mg} / \mathrm{kgBB}$ yang memiliki rata-rata immobility time pada hari ke-7 yaitu 36,33 detik, dengan ekstrak dosis $15 \mathrm{mg} / \mathrm{kgBB}$ memiliki nilai rata-rata immobility time pada hari ke-7 yaitu 48,67 detik dan dengan ekstrak dosis $1,5 \mathrm{mg} / \mathrm{kgBB}$ memiliki nilai rata-rata pada hari ke-7 yaitu 60,33 detik. Hal ini menunjukkan bahwa amitriptilyn memiliki ekfektivitas antidepresan yang paling baik dibanding dengan ekstrak batang serai.
Pada kontrol negatif (CMC Na $0,5 \%)$ memiliki rata-rata immobility time paling tinggi pada hari ke-7 yaitu 223,67 detik jika dibandingkan denga hari ke-1 yaitu 208 detik dan hari ke-3 yaitu 128,67 detik. CMC Na 0,5\% memiliki waktu diam mencit yang lebih sedikit dengan perolehan ratarata immobiliti time pada hari ke- 7 yang paling tinggi yaitu 223,67 detik jika dibandingkan dengan amitriptilyn dosis $3,25 \mathrm{mg} / \mathrm{kgBB}$, dengan ekstrak dosis $150 \mathrm{mg} / \mathrm{kgBB}$, dengan ekstrak dosis $15 \mathrm{mg} / \mathrm{kgBB}$ dan dengan ekstrak dosis 1,5 $\mathrm{mg} / \mathrm{kgBB}$. Hal ini menunjukkan bahwa CMC Na tidak memiliki zat aktif sebagai antidepresan.

Pada dosis ekstrak 1,5 $\mathrm{mg} / \mathrm{kgBB}$ memiliki penurunan ratarata immobility time lebih kecil pada hari ke-7 yaitu 60,33 detik dibanding pada hari ke-1 yaitu 80,67 detik dan hari ke-3 yaitu 64,33 detik. Pada ekstrak dosis 1,5 $\mathrm{mg} / \mathrm{kgBB}$ memiliki waktu diam mencit lebih lama jika dibandingkan dengan CMC Na 0,5\% dan memiliki waktu diam mencit lebih sedikit dibandingkan dengan ekstrak dosis $150 \mathrm{mg} / \mathrm{kgBB}$, dengan ekstrak dosis $15 \mathrm{mg} / \mathrm{kgBB}$ dan dengan amitriptilyn dosis $3,25 \mathrm{mg} / \mathrm{kgBB}$.

Pada ekstrak dosis 15 $\mathrm{mg} / \mathrm{kgBB}$ memiliki penurunan ratarata immobility time paling tinggi pada hari ke-7 yaitu 48,67 detik dibandingkan dengan hari ke-1 yaitu 68,33 detik dan hari ke-3 yaitu 56,33 detik. Pada dosis ekstrak 15 mg/kgBB memiliki waktu 
diam mecit lebih lama dibanding dengan ektrak dosis $1,5 \mathrm{mg} / \mathrm{kgBB}$ dan CMC Na 0,5\%. Tetapi memiliki waktu diam mencit lebih sedikit dibanding dengan ektrak dosis 150 $\mathrm{mg} / \mathrm{kgBB}$ dan amitriptilyn dosis $3,25 \mathrm{mg} / \mathrm{kgBB}$.

Pada ekstrak dosis 150 $\mathrm{mg} / \mathrm{kgBB}$ memiliki rata-rata immobility time paling sedikit pada hari ke-7 yaitu 36,33 detik dibandingkan dengan hari ke-1 yaitu 61,67 detik dan pada hari ke3 yaitu 54,33 detik. Pada ekstrak dosis $150 \mathrm{mg} / \mathrm{kgBB}$ memiliki waktu diam mencit yang lebih lama jika dibandingkan dengan ekstrak dosis $15 \mathrm{mg} / \mathrm{kgBB}$, dengan ekstrak dosis $1,5 \mathrm{mg} / \mathrm{kgBB}$ dan dengan CMC Na $0,5 \%$. Tetapi ekstrak dosis 150 $\mathrm{mg} / \mathrm{kgBB}$ memiliki waktu diam mencit lebih sedikit dibandingkan dengan pembanding amitriptilyn. Hal ini menunjukkan bahwa ektrak batang serai dosis tinggi yaitu 150 $\mathrm{mg} / \mathrm{kgBB}$ memiliki efektivitas sebagai antidepresan yang lebih efektif dibanding ekstrak batang serai dosis sedang $15 \mathrm{mg} / \mathrm{kgBB}$ dan

\section{KESIMPULAN}

Dari hasil penelitian yang dilakukan dapat disimpulkan bahwa ekstrak batang serai (Cymbopogon nardus (L.) Rendle) memiliki efektivitas sebagai antideprasan karena betang serai memiliki kandungan eugenol yang bekerja dengan cara menghambat Mono Amine oxidase (MAO) dan ekstrak batang serai (Cymbopogon nardus (L.) Rendle) yang paling efektif ekstrak batang serai dosis rendah $1,5 \mathrm{mg} / \mathrm{kgBB}$, akan tatapi ekstrak batang serai dosis tinggi 150 $\mathrm{mg} / \mathrm{kgBB}$ tidak lebih efektif sebagai antidepresan dibandingkan amitriptilyn dosis $3,25 \mathrm{mg} / \mathrm{kgBB}$.

Amtriptiliyn merupakan obat antidepresan golongan trisiklik yang bekerja dengan cara menghambat ambilan kembali (reuptake) neurotransmiter seperti norepinephirine dan serotonin pada sistem saraf pusat sehingga kinerja otak akan membaik dan gejala depresi secara berangsur akan berkurang (Ratna, 2018).

Pada ekstrak batang serai mengandung eugenol, eugonol merupakan golongan dari flovonoid (Mayangsari, 2017). Eugenol ini memiliki efek sebagai antidepresan dengan mekanisme penghambatan proses deaminasi oksidatif katekolamin di mitokondria. Akibatnya kadar norepinephrin, epinephrin, dan serotonin dalam otak naik (Athifah, 2016).

sebagai antidepresan yaitu dosis $150 \mathrm{mg} / \mathrm{kgBB}$. Akan tetapi ekstak batang serai dosis $150 \mathrm{mg} / \mathrm{kgBB}$ tidak lebih efektif dari amitriptilyn sebagai antidepresan.

\section{DAFTAR PUSTAKA}

Athifah, Ishmah Almuqaffa. (2016). Uji Aktivitas Antidepresan Ekstrak Etanol Daun Kemangi (Ocimum americanum L.) Pada Mencit Jantan Galur Swiss Webster. Halamn 30. 
Depkes RI. (1979). Farmakope Indonesia. Edisi Ketiga. Jakarta: Departemen Kesehatan Republik Indonesia. Halaman 591.

Hawari, Dadang. (2018). Manajemen Stres Cemas dan depresi. Jakarta: FKUI.

Istriningsih, Endang. (2018). Efek Antidepresan Kombinasi Infusa Buji Pala (Myristica fragrans) dan daun Kemangi (Ocimum basilicum) Pada Mencit Jantan Putih (Mus musculus). Slawi: Sekolah Tinggi Ilmu Kesehatan Bhakti Mandala Husada.

Jaya, Kusnadi. (2018). Keperawatan Jiwa. Tangerang Selatan: Binarupa aksara Publisher.

Lisnawati, Risa. (2015). Efektivitas Ekstrak (Momordica charantia L.) Sebagai Antidepresan Terhadap Mencit Jantan Putih (Mus muscullus). Jakarta: Akademi Farmasi dan Makanan.

Mayangsari, Putik Pamilutsih. (2017). Antidepresan Kombinasi Ekstrak Etanol Bunga Cengkeh (Syzgium aromaticum) dan Ekstrak Etanol Kulit Pisang (Musa paradisiaca) Terhadap Peningkatan Aktivitas
Lokomotor dan Penurunan Immobility Time Pada Mencit. Surakarta: Fakultas Farmasi Universitas Muhammadiyah Surakarta. Halaman 5.

Nuzband, Khansa Nabila. (2014). Uji Aktivitas Antidepresan Ekstrak Bunga Cengkeh (Syzygium aromaticum) pada Mencit Putih (Mus musculus) Jantan dengan Metode Forced Swim Test. Samarinda: Akademi Farmasi Samarinda.

Praza S. dkk. (2016). Pengaruh Pemberian Ekstrak Etanol Daun Sirsak (Annona muricata L.) Sebagai Antidepresan Terhadap Mencit Swiss Webstar Jantan. Prosiding Farmasi. Volume 2 No. 1. ISSN: 2460-6472.

Ratna, Ajeng Ningtyas, dkk. (2018). Farmakoterapi Depresi dan Pengaruh Jenis Kelamin Terhadap Infeksi Antidepresan. Fakultas Farmasi. Universitas Padjadjaran. Halaman 187. 